\title{
ARE ONLINE COURSES CANNIBALIZING STUDENTS FROM EXISTING COURSES?
}

\author{
Joseph K. Cavanaugh \\ Department of Business \\ Wright State University, Lake Campus
}

\begin{abstract}
One of the reasons most often cited for the increasing number and popularity of online courses is the format's ability to provide access to students who cannot attend conventionally delivered face-to-face courses. Are these underserved students in fact the ones enrolling in online courses? Or are online course enrollees the same students who would otherwise be taking face-to-face courses? This analysis uses student registration information from six different online courses at two campuses of a Midwestern university to investigate how students taking online courses compare to the entire student population. In particular, this study addresses whether or not students take online courses to eliminate significant commuting time when they are located long distances from campus.
\end{abstract}

\section{KEYWORDS}

Student Demographics, Online Comparison, Student Location, Distance Learning

\section{INTRODUCTION}

As of February 2005, about $70 \%$ of all U.S. households have home internet access. The internet penetration rate has increased by $110.7 \%$ from 2000 to 2005 [1]. Mirroring the dramatic growth in the overall usage of the internet, similar growth has occurred in the number of online courses and the number of students enrolled in such courses in the United States. From 1998 to 2001, enrollment in distance education courses increased by over $100 \%$, and the number of courses offered increased by more than $200 \%$ [2, 3, 4]. In the fall of 2003, nearly two million students took at least one online course, and over $90 \%$ of all public higher education institutions offered online courses [5].

A number of studies have investigated student data from online courses. Many of these studies have looked at student satisfaction and dropout rates. Researchers have found that students in online courses are equally satisfied and learn as effectively as students in face-to-face courses $[6,7,8,9]$. The research concerning the dropout rates of students taking online courses has been mixed. A number of investigators have found that online courses tend to have higher dropout rates than face-to-face courses [9, 10, 11]. But retention rates are difficult to measure, and others have found the opposite result or have suggested that the comparison is not appropriate $[12,13]$.

Many researchers cite the advantages of online courses $[14,15]$. A commonly mentioned advantage is the provision of access to students who either require the flexibility to take courses on irregular schedules or live a significant distance from campus. These courses are particularly appealing to working professionals, single parents, or those whose jobs require travel. Specifically, researchers have found that students choose to take online courses due to their flexibility $[16,17]$ and because of work or family responsibilities [18, 19]. Students taking online courses are more likely to be women [18, 19, 20, 21], older than other students [18, 19], and taking courses part-time and/or working full-time [21]. 
Although commuting time is often mentioned as a reason why students take online courses, little research provides evidence to support this supposition. In fact, Bocchi, Eastman, and Swift [17], in a survey of online MBA students, expected to find that the distance to campus from work or home would be an important reason for a student's enrollment. However, students reported that they were more likely to choose the online format for family reasons and greater flexibility with work schedules. The geographic distance to campus from work or home was found not to be relevant to the student's enrollment decision. This study focuses on this issue by analyzing directly the commuting time that online students have when traveling to campus. An analysis of registrar data is also performed in order to determine if the online students are similar or different in other characteristics when compared to the typical student profile. If the online students are significantly different from the typical student, and especially if they face long commutes, then it is unlikely that the online courses are cannibalizing students from the existing face-toface courses.

\section{BACKGROUND INFORMATION}

This study uses the registration data of students who have taken six different online courses during the spring quarter of 2004 at Wright State University. Wright State University is a public university located in Dayton, Ohio, with an enrollment of approximately 16,700 students. Wright State University has one branch campus, the Lake Campus, located ninety miles north of the main campus with an enrollment of approximately 1,000 students.

As has occurred nationwide, at Wright State University the number of online courses and the number of students enrolled in those courses have grown rapidly. Over the past four years, the number of web courses offered has on average increased $84 \%$ annually. Only recently has this rate of growth started to level off.

During the fall quarter of 2004, approximately 60 courses were taught completely online. The sample used in this study consisted of six of these courses selected from different disciplines and colleges in order to be representative of the university's wide variety of online offerings. Two of the six were graduate level courses, and five of the six were taught by faculty located on the main campus. Students can take the online courses from either campus but typically take courses from the campus nearest to their homes. Four students, however, lived closest to the Dayton Campus but took the course offered by a faculty member from the Lake Campus, and fifteen students located nearer to the Lake Campus took courses taught by faculty teaching on the Dayton Campus. A total of 94 students enrolled in these six courses. Table 1 contains a summary of information about the courses used in this study.

Course

Macroeconomics EC205

Administration and

Supervision of Educational

Technology EDT895

Modern Europe HIS103

Introduction To Nursing

Informatics NUR210

Vocational Evaluation and Job Placement Techniques

\section{Campus}

Taught From

Lake

Dayton

Dayton

Dayton

Dayton

\section{Course Level}

Undergraduate

Graduate

Undergraduate

Undergraduate

Graduate

\section{Total Number of Students}

15

13

27

10

12
Students on

Other Campus

4

2

8

0

0 


\section{RHB711}

\section{University Honors Seminar UH400}

Total
Dayton Undergraduate

94
5

19

Table 1: Summary of Course Characteristics

\section{DEMOGRAPHIC ANALYSIS}

The students taking the online courses were older, had a higher cumulative GPA, and were more likely to be female and part time than the typical Wright State University student. The percentage of minority students taking these online courses was similar to that in the overall student population, and the grades received by these students for these online courses was similar to their cumulative grade point averages.

In these six courses, online students were on average 27.8 years old, whereas the university student population averaged 25.0 years of age. Online students taking graduate-level courses had the largest age disparity: the overall university graduate student body is on average 31.4 years old compared to 38.2 years for the online graduate students in the sample. The undergraduate student body is on average 23.0 years old compared to 24.1 years for the online undergraduates in the sample. On average, $58.0 \%$ of Wright State University students are female, but $74.5 \%$ of the online students studied were female. This percentage of female online students is reasonably consistent with that reported by Wojciechowski [21], who found the proportion of females in her study to be $69 \%$. The proportion of the undergraduate students in the sample who were part time (taking one or two courses) was $30.4 \%$, whereas the overall proportion of part-time undergraduates is $16.7 \%$ for the university. Minorities make up $12.0 \%$ of the total university population, a number very close to the $11.7 \%$ of the online students who identified themselves as belonging to a minority group.

Table 2 provides a summary of a number of the comparisons made between the online students and the entire student population.

\begin{tabular}{|c|c|c|c|c|}
\hline & $\begin{array}{c}\text { Average } \\
\text { Age }\end{array}$ & $\begin{array}{l}\text { Percentage } \\
\text { Female }\end{array}$ & $\begin{array}{l}\text { Percentage of } \\
\text { Undergraduate } \\
\text { Part Time }\end{array}$ & $\begin{array}{c}\text { Percentage } \\
\text { Minority }\end{array}$ \\
\hline $\begin{array}{l}\text { Online Students } \\
(n=94)\end{array}$ & 27.8 years & $74.5 \%$ & $30.4 \%$ & $11.7 \%$ \\
\hline $\begin{array}{l}\text { University Wide } \\
(\mathrm{n}=16,700)\end{array}$ & 25.0 years & $58.0 \%$ & $16.7 \%$ & $12.0 \%$ \\
\hline $\begin{array}{l}\text { Chi-Square Test } \\
\text { of Independence }\end{array}$ & & $\begin{aligned} \mathrm{X}^{2} & =10.45 \\
p & =0.00\end{aligned}$ & $\begin{aligned} \mathrm{X}^{2} & =12.57 \\
p & =0.00\end{aligned}$ & $\begin{array}{c}\mathrm{X}^{2}=.01 \\
p=0.92\end{array}$ \\
\hline
\end{tabular}

Undergraduate online students also differed from students across the university according to the number of hours they had taken (Table 3). Students with more credit hours tended to be more likely to enroll in the online courses. (The chi-square test of independence with three degrees of freedom has a test statistic larger than 25 and a $p$ value of 0.00.) Graduate students were almost equally as likely to enroll online as enroll in face-to-face courses. Students taking online courses had higher cumulative grade point averages but received grades in the online courses that were similar to their cumulative grade point averages. University-wide, undergraduate students have an average cumulative GPA of 2.91, whereas the online 
undergraduates in this survey had a cumulative GPA of 3.45. For these online courses, the average grade was a 3.43. So the students received virtually the same grade from this online course as they had received in all courses they had taken up to and including this one. This relationship also holds true when the students are separated by class level (Table 3). This result is consistent with Wojciechowski [21], who found that older students and students with higher overall GPAs performed significantly better in online courses. For the graduate students, the average GPA across the university is not available. As was the case for the undergraduates, the cumulative GPA for the graduate students in this sample was 3.60, which is reasonably close to the average grade of 3.44 that they received in the online courses.

\begin{tabular}{|l|c|c|c|c|c|c|}
\multicolumn{9}{c}{ University Wide } & \multicolumn{2}{c|}{ Online Students } \\
\hline $\begin{array}{l}\text { Hours } \\
\text { Taken }\end{array}$ & Status & $\begin{array}{c}\text { Percent of } \\
\text { All Students }\end{array}$ & $\begin{array}{c}\text { Cumulative } \\
\text { GPA }\end{array}$ & $\begin{array}{c}\text { Percent of } \\
\text { Students } \\
\text { in Sample }\end{array}$ & $\begin{array}{c}\text { Cumulative } \\
\text { GPA }\end{array}$ & $\begin{array}{c}\text { Average } \\
\text { Course Grade }\end{array}$ \\
\hline $\mathbf{0 - 4 4}$ & Freshman & $33.9 \%$ & 2.3 & $7.2 \%$ & 3.33 & 3.20 \\
\hline $\mathbf{4 5 - 8 9}$ & Sophomore & $19.4 \%$ & 2.81 & $18.8 \%$ & 3.53 & 3.31 \\
\hline $\mathbf{9 0 - 1 3 4}$ & Junior & $18.8 \%$ & 2.86 & $31.9 \%$ & 3.21 & 3.27 \\
\hline $\mathbf{1 3 5 +}$ & Senior & $28.0 \%$ & 2.99 & $42.0 \%$ & 3.63 & 3.66 \\
\hline All & & & 2.91 & & 3.45 & 3.43 \\
\hline & Graduate & $26.5 \%$ & & $26.6 \%$ & 3.60 & 3.44 \\
\hline
\end{tabular}

Table 3: Grade Comparison

\section{COMMUTING TIME}

The online students tended to live farther from campus; they were less likely to live on campus; and they tended to take only online courses. For the sample, the average distance from the student's address to the nearer campus was 39 miles. The average commuting time to campus was 48 minutes. Within the sample, 29 students, or 31\%, were taking only online courses. The majority of these students were taking only one course, but eleven students were taking two online courses and three students were taking three online courses. Not surprisingly, the commuting time would have been significantly longer for these students. Thirty-eight percent of these students would have had a commuting time of over an hour in each direction.

Sixty-eight percent of all the students attending the university live within ten miles of campus. For the online sample, only $41 \%$ lived within ten miles of campus (Table 4). Seven students taking online classes lived on campus and therefore were assigned a zero for no commuting time. These seven students represent $7.4 \%$ of the total sample of online students. For the university as a whole, $16.7 \%$ of students live on campus.

$\begin{aligned} & \text { Online Students } \\ & (n=94)\end{aligned}$
University Wide
(n= 16,700)
Chi-Square Test
of Independence

Percentage Located Within 10 Miles of Campus

$$
\begin{gathered}
41 \% \\
68 \% \\
X^{2}>25 \\
p=0.00
\end{gathered}
$$

\section{Percentage Located On Campus}

Table 4: Summary Comparison of Student Location

$$
\begin{gathered}
16.7 \% \\
7.4 \% \\
\mathrm{X}^{2}=5.83 \\
p=0.02
\end{gathered}
$$


It is entirely possible that online students living within ten miles of campus could have taken the courses on campus. The other reported demographic data, however, suggests that these students differ in many ways compared to the typical student. Are they taking these courses only because the courses are available online? Given this data there is no way to be certain; it could be just a coincidence that the students who enroll in online courses are significantly different than the typical students. For the $31 \%$ of the online students who were taking only online courses and therefore avoided significant commutes, the argument against student cannibalization is stronger. It is likely that at least some of these students, who differ in many significant ways from the average student and live a significant distance from campus, would not have taken the courses if they were not available online.

\section{CONCLUSION}

This analysis focuses on commuting time as a reason for students taking online courses and compares online students to the average student at Wright State University. There are, however, some significant limitations to this study. When making the demographic comparisons, the online students were included in all the university student population averages. Since only a small fraction of the total student body took courses online, the differences reported in this study would have been slightly larger if the online students were compared to the non-online students. More important, this investigation looked at one particular institution at one point in time. A more comprehensive study would include many different types of institutions across the country over a significant time period. Additionally, only the distance between the student's home and the institution is considered. The distance between the student's work location and the institution is also important when considering if the commuting time is a significant reason for taking the course online. Information concerning course dropout rates, students' technological experiences, and student course evaluations were also not investigated here but are important when comparing online students with face-to-face students. This data was unavailable.

Given these limitations, this study does provide evidence to support the argument that students taking online courses differ in many significant ways from the average student. Online students are more likely to be female and older and are less likely to live on campus. They live significantly further from campus and are more likely to be part-time students who often take only online courses. The online students have higher cumulative grade point averages than the typical student, and they receive grades in the online courses that are similar to their cumulative grade point averages. These courses appear to be reaching out to non-traditional but academically strong students that are unable or unwilling to take face-to-face courses due to long commuting times. Although attempting to determine why students take online courses is a complex issue, the results from this study indicate that it is less likely that online courses are cannibalizing a significant number of students taking face-to-face courses.

\section{REFERENCES}

1. Internet World Stats. America Internet Usage and Population Statistics, 2005. Online: http://www.Internetworldstats.com/stats2.htm.

2. National Center for Education Statistics (NCES). A Profile of Participation in Distance Education: 1999-2000. Education Statistics Quarterly 4(4): 2002. Online: http://nces.ed.gov/pubsearch/pubsinfo .asp?pubid=2003605.

3. National Center for Education Statistics (NCES). Distance Education at Degree-Granting Postsecondary Institutions: 2000-2001. U.S. Department of Education, National Center for Education Statistics Report, 2003. Online: http://nces.ed.gov/pubsearch/pubsinfo.asp?pubid=2003017.

4. Kieman, V. A survey documents growth in distance education in late 1990s. Chronicle of Higher Education 49(48): A28, 2003. 
5. Allen, I. E. and J. Seaman. Entering the mainstream: The quality and extent of online education in the United States, 2003 and 2004. Needham, MA: The Sloan Consortium, 2004. Online: http://www.sloan-c.org/resources/survey.asp.

6. Neuhauser, C. Learning style and effectiveness of online and face-to-face instruction. The American Journal of Distance Education 16(2): 99-113, 2002.

7. Ngu, B. Online instruction versus face-to-face instruction at UNIMAS. International Journal of Educational Technology 3(1): 1-19, 2002.

8. Allen, M., J. Bourhis, N. Burrell, and E. Malbry. Comparing student satisfaction with distance education to traditional classrooms in higher education: A meta-analysis. The American Journal of Distance Education 16(2): 83-97, 2002.

9. Hiltz, S. Impacts of college-level courses via asynchronous learning networks: Some preliminary results. Journal of Asynchronous Learning Networks 1(2): 1-19, 1997.

10. Xenos, M., C. Pierrakeas, and P. Pintelas. A survey on student dropout rates and dropout causes concerning the students in course of informatics of the Hellenic Open University. Computers \& Education 36(1): 361-377, 2002.

11. Muse, H. The Web-based community college student: An examination of factors that lead to success and risk. The Internet and Higher Education 6(1): 241-261, 2003.

12. Carr, S. As distance education comes of age, the challenge is keeping the students. Chronicle of Higher Education 46(23): A39, 2000.

13. Howell, S., D. Laws, and N. Lindsay. Reevaluating course completion in distance education: Avoiding the comparison between apples and oranges. Quarterly Review of Distance Education 5(4): 243-252, 2004.

14. Flowers, J. Online learning needs in technology education. Journal of Technology Education 13(1): 17-30, 2001.

15. Warbington, R. The advantages of online learning. Women in Business 53(6): 23-24, 2001.

16. Turner, F. and J. Crews. Bricks and clicks: A comparative analysis of online and traditional education settings. International Journal of Instructional Technology and Distance Learning 2(4): 17, 2005.

17. Bocchi, J., J. Eastman, and C. Swift. Retaining the online learner: Profile of students in an online MBA program and implications of teaching them. Journal of Education for Business 79(4): 245-254, 2004.

18. Wirt, J., S. Choy, and P. Rooney. The Condition of Education 2004: Adult Participation in WorkRelated Learning. U.S. Department of Education, National Center for Education Statistics, 2004. Online: http://nces.ed.gov/programs/coe/2004/section1/indicator07.asp.

19. Zirkle, C. Distance education and career and technical education: A review of the research literature. Journal of Vocational Education Research 28(2): 2003. Online: http://scholar.lib.vt.edu lejournals/JVER/v28n2/zirkle.html.

20. Kader, B. Gearing women towards embracing online learning. Computimes (Malaysia), April 16, 2001.

21. Wojciechowski, A. Individual student characteristics: Can any be predictors of success in online classes? Online Journal of Distance Learning Administration 8(2): 2005. Online: http://www.westga .edu/\%7Edistance/ojdla/summer82/wojciechowski82.htm.

\section{ABOUT THE AUTHOR}

Joseph K. Cavanaugh is an associate professor of economics at Wright State University, Lake Campus. His research interests are in distance education and economic education. He has presented work in these areas at numerous state, regional, and national conferences. In 1990 he completed an M.A. in Economics from Miami University, Ohio, and in 1994 he received his Ph.D. in Economics from the University of Kentucky. 